\title{
Cytotoxic effect of jasmonate and methyl jasmonate on a canine macrophage tumor cell line
}

\author{
HERNANDES, C.; CARDOZO, G.P.; FRANÇA, S.C.; FACHIN, A.L.; MARINS, M.*; LOURENÇO, M.V. \\ Universidade de Ribeirão Preto, UNAERP, CEP: 14096-900, Ribeirão Preto-Brasil *marins@heranza.com.br
}

\begin{abstract}
Cancer is one of the leading causes of death in dogs, a fact that has boosted the investigation for new more specific antitumor drugs. This study evaluated the antitumor activity of jasmonates in the canine macrophage cell line DH82 (ATCC \# CRL-10389) isolated from a case of malignant histiocytoma. The activities of methyl jasmonate and jasmonic acid were compared to that of doxorubicin by the MTT assay. Methyl jasmonate resulted in the highest inhibition of cell growth $(82.2 \%)$, followed by doxorubicin ( $80.7 \%$ ) and jasmonic acid (36.5\%). More detailed studies regarding the action of jasmonates on animal health are necessary, but the present results indicate methyl jasmonate as an alternative to the development of drugs for the treatment of canine oncologies.
\end{abstract}

Key words: jasmonates, histiocytoma, dogs

RESUMO: Efeito citotóxico de jasmonato e metiljasmonato em linhagem tumoral celular de macrófagos caninos. O câncer é uma das principais causas de morte em cães o que tem impulsionado a pesquisa por novos antitumorais com ação mais específica. Neste trabalho, a atividade antitumoral de jasmonatos foi avaliada na linhagem de macrófagos caninos DH82 (ATCC \# CRL-10389), a qual é originada de um caso de histiocitoma maligno. A atividade do metil jasmonato $(\mathrm{MJ})$ e do ácido jasmônico (AJ) foram comparadas à doxorrubicina, através do método de coloração MTT. O MJ apresentou maior inibição $(82,2 \%)$, seguido da Doxorrubicina $(80,7 \%)$ e AJ (36,5\%). Estudos mais completos da ação dos jasmonatos na saúde animal ainda são necessários, porém, os dados deste trabalho apontam o MJ como alternativa para o desenvolvimento de drogas para o tratamento das oncologias caninas.

Palavras-chave: jasmonatos, histiocitoma, cães

The extraordinary morphological diversity among dogs is the result of decades of breeding by man, based on the selection of traits such as height, body weight, pelage and behavior (Galibert \& Andre, 2006; Cruz et al., 2008). Since breeding programs are designed to maintain the large number of current breeds, crossing between individuals of the same breed, which are often closely related, predominates. This increases the probability of genetic diseases and more than 360 such diseases, including cancer, have been described in the dog (Galibert \& Andre, 2006; Cruz et al., 2008). Similar to humans, advances in veterinary medicine, pet food industry and veterinary drugs have increased the longevity of domestic dogs. Concomitantly, the incidence of cancer has also increased, especially among older animals. It is estimated that one in 3-4 dogs will develop some type of cancer, a rate twice as high as that observed for humans.
Malignant histiocytosis, also known as histiocytic sarcoma, is one of the most aggressive cancers. It is a fast-growing tumor derived from myeloid cells, which can lead to death within a period of 2 to 4 months. The disease is characterized by the rapid development of metastases, mainly involving the spleen, lymph nodes, bone marrow, lungs, and liver (Hafeman et al., 2010). In view of its aggressiveness, this tumor is resistant to conventional chemotherapy (Hafeman et al., 2010).

Jasmonic acid (JA) and methyl jasmonate (MJ) belong to a novel class of compounds with proven antitumor activity. In humans, MJ has been shown to inhibit the growth of cancer cells, inducing cell death in breast and prostate carcinoma, melanoma, lymphoma and leukemic cells without affecting normal lymph nodes (Fingrut \& Flescher, 2002). In addition, jasmonates are able to kill drug-resistant cancer cells (Fingrut et al., 2005). These authors showed that

Recebido para publicação em 13/07/2010

Aceito para publicação em 04/06/2011

Rev. Bras. PI. Med., Botucatu, v.14, n.1, p.122-124, 2012. 
jasmonates act on both cells, those resistant due to a mutation in the tumor suppressor gene p53, which results in uncontrolled proliferation and malignancy, and those in which resistance is mediated by the Pglycoprotein efflux pump. Although chemotherapy is one of the most effective treatments to combat cancer and despite advances in veterinary oncology, the incidence of canine cancer continues to rise, with euthanasia being necessary in most cases. Thus, new antitumor drugs that would be effective in the treatment of different types of canine cancer, many of them similar to human cancers, need to be tested. In view of the antitumor effects of jasmonates observed in humans, the objective of the present study was to evaluate the effect of JA and MJ on a canine macrophage cell line (DH82) isolated from a malignant histiocytoma (Wellman et al., 1988).

For the assays, the DH82 cell line was grown in DMEM medium supplemented with $10 \%$ bovine calf serum in an oven at $37^{\circ} \mathrm{C}$ and atmosphere of $5 \% \mathrm{CO} 2$. After culture, the cells were transferred to 96-well plates at a concentration of $2 \times 10^{5}$ cells/well and cultured for an additional $24 \mathrm{~h}$. JA, MJ and doxorubicin (Sigma Aldrich) were dissolved in dimethylsulfoxide (DMSO; Sigma Aldrich) and diluted in medium to final concentrations of $630.9,420$ and $210 \mu \mathrm{g} \mathrm{mL}^{-1}$ for JA, 672,448 and $224 \mu \mathrm{g} \mathrm{mL}^{-1}$ for MJ (corresponding to 3 ,
2 and $1 \mathrm{mM}$ ), and $4 \mu \mathrm{g} \mathrm{mL}-1$ for doxorubicin. The concentration of DMSO did not exceed $0.6 \%$. The substances were added to the plate and the plates were incubated for $48 \mathrm{~h}$. Cell viability was evaluated by the thiazolyl blue tetrazolium bromide (MTT) assay (Sigma Aldrich) using a dye concentration of $5 \mathrm{mg}$ $\mathrm{mL}^{-1}$. This assay is based on the cleavage of the tetrazolium salt MTT to blue formazan crystals by viable cells. The crystals were then dissolved in 200 $\mu \mathrm{L}$ DMSO and optical density was read in a Thermoplate reader at a wavelength of $550 \mathrm{~nm}$.

The assays were carried out in triplicates and the results were analyzed by ANOVA using the SISVAR V.4.3 program. Treatment means were compared by the Scott-Knott test at a level of significance of $5 \%$ (Scott \& Knott, 1974). The results were found to be linear for all substances tested (Figure 1).

At the highest concentration tested, JA inhibited the growth of the tumor cell line by only $36.5 \%$. In contrast, treatment with $\mathrm{MJ}$ resulted in an inhibition of cell growth of $82.2 \%$, a percentage higher than that observed for doxorubicin (80.7\%) (Figure 2).

Cancer is one of the most important causes of mortality in animals and humans, especially in the veterinary area in which treatment is often only palliative. Although doxorubicin is widely used for the

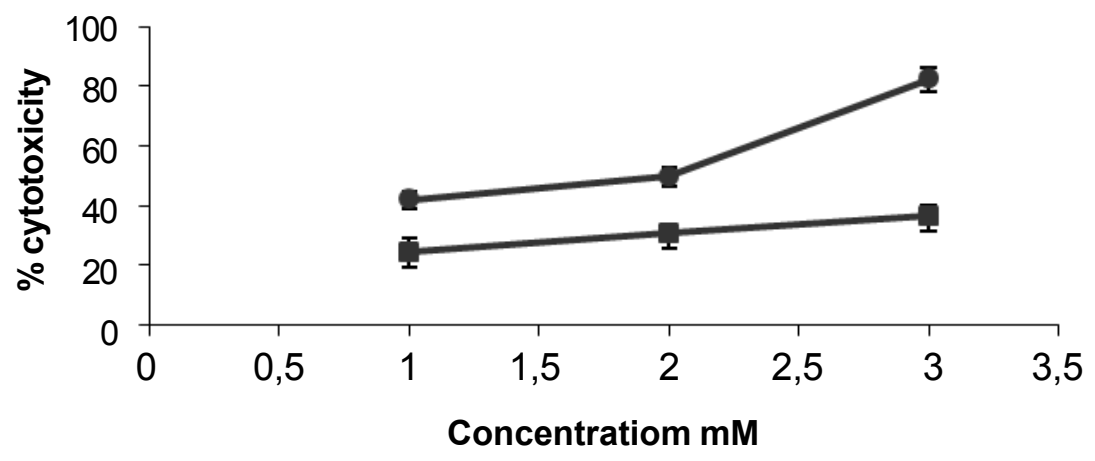

FIGURE 1. Percent inhibition of DH82 cells by jasmonic acid (JA) and methyl jasmonate (MJ). $\rightarrow-(M J) \rightarrow-(A J)$.

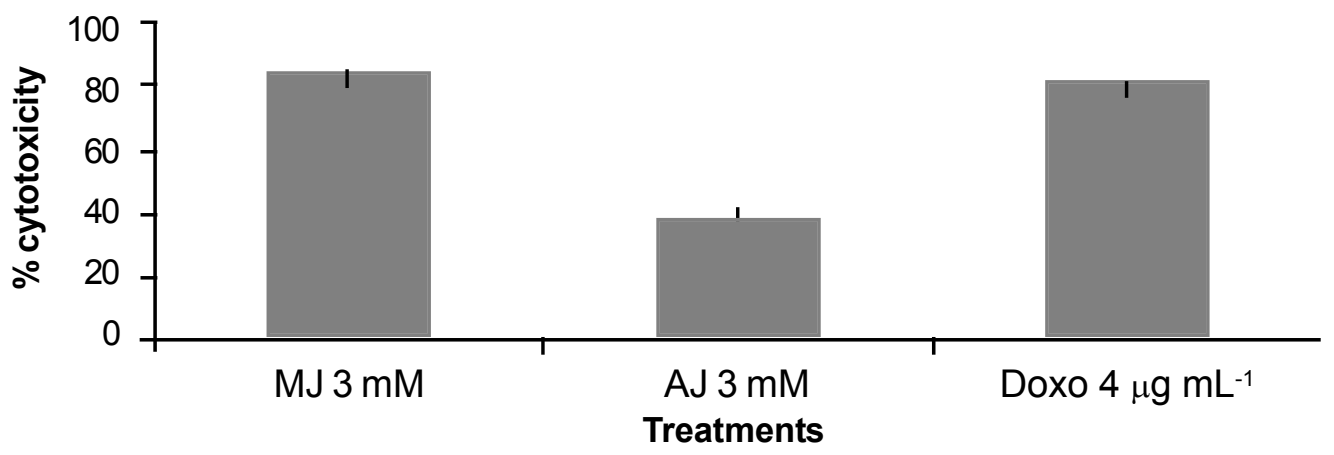

FIGURE 2. Comparison of the percent inhibition of DH82 cells by methyl jasmonate (MJ), jasmonic acid (JA) and doxorubicin (Doxo). 
treatment of canine oncologies, even therapeutic doses of the drug result in the development of cardiomyopathies (Silva \& Camacho, 2005).

According to the United States National Cancer Institute, only substances presenting 50\% inhibition of cell growth at concentrations of less than $4 \mu \mathrm{g} \mathrm{mL}^{-1}$ are considered to be active compounds (Villarreal et al., 1994). Although the concentrations of MJ and JA tested in this study were higher than those recommended, Rotem et al. (2005) demonstrated the absence of toxicity of $\mathrm{MJ}$ at these doses to normal cells in vitro and in vivo, thus permitting its use for the treatment of cancer.

In view of the similarity of canine and human cancer, studies regarding the activity of novel antitumor drugs might be useful for the establishment of new chemotherapies in both species. For example, canine histiocytosis is analogous to Langerhans cell histiocytosis in humans, which mainly affects children and adolescents. Thus, MJ might be a potential target for the development of a chemotherapeutic agent that can be used as an additional alternative to treatments currently employed in dogs.

\section{ACKNOWLEDGMENT}

This study was supported by funds from FAPESP (grants 07/07234-6, 08/09815-9, 07/00703$0)$. We thank CAPES for schoolarships granted to C.H. and G.P.C., the staff of the Biotechnology UnitUNAERP for general support, and K. Markendorf for revision of the English text.

\section{REFERENCE}

CRUZ, F. et al. The legacy of domestication: accumulation of deleterious mutations in the dog genome. Molecular Biology and Evolution, v.25, n.11, p.2331-6, 2008.

FINGRUT, O.; FLESCHER, E. Plant stress hormones suppress the proliferation and induce apoptosis in human cancer cells. Leukemia, v.16, n.4, p.608-16, 2002. FINGRUT, O. et al. Jasmonates induce nonapoptotic death in high-resistance mutant p53-expressing Blymphoma cells. British Journal of Pharmacology, v.146, n.6, p.800-8, 2005.

GALIBERT, F.; ANDRE, C. The dog genome. Genome Dynamics, v.2, p.46-59, 2006.

HAFEMAN, S. et al. Evaluation of liposomal clodronate for treatment of malignant histiocytosis in dogs. Cancer Immunology, Immunotherapy, v.59, n.3, p.441-52, 2010. ROTEM, R. et al. Jasmonates: novel anticancer agents acting directly and selectively on human cancer cell mitochondria. Cancer Research, v.65, n.5, p.1984-93, 2005.

SCOTT, A.J.; KNOTT, M.A. A cluster analysis method for grouping means in the analysis of variance. Biometrics, v.30, n.2, p.507-12, 1974.

SILVA, C.E.V.; CAMACHO, A.A. Alterações ecocardiográficas em cães sob tratamento prolongado com doxorrubicina. Arquivo Brasileiro de Medicina Veterinária e Zootecnia, v.57, n.3, p.300-6, 2005.

VILLAREAL, M.L. et al. Cytotoxic and antimicrobial screening of selected terpenoids from Asteraceae species. Journal of Ethnopharmacology, v.42, n.1, p.2534, 1994.

WELLMAN, M.L. et al. A macrophage-monocyte cell line from a dog with malignant histiocytosis. In Vitro Cellular \& Developmental Biology, v.24, n.3, p.223-32, 1988. 